Tersedia online di: http://ejournal-balitbang.kkp.go.id/index.php/jkpi
e-mail:jkpi.puslitbangkan@ gmail.com

\title{
PENGELOLAAN SUMBERDAYA PERIKANAN MELALUI PENDEKATAN EKOSISTEM DI PAPARAN BANJIRAN GIAM SIAK KECIL
}

\section{FISHERIES RESOURCES MANAGEMENT THROUGH ECOSYSTEM APPROACH IN GIAM SIAK KECIL FLOODPLAIN}

\author{
Kamaluddin Kasim¹, Eko Prianto', Husnah ${ }^{1}$ dan Setiya Triharyuni' \\ 1 Pusat Riset Perikanan \\ Gedung Balitbang KP II, JI. Pasir Putih II Ancol Timur, Jakarta Utara-14430, Indonesia \\ Teregistrasi I tanggal: 24 Nopember 2017; Diterima setelah perbaikan tanggal: 27 Desember 2017; \\ Disetujui terbit tanggal: 02 Januari 2018
}

\begin{abstract}
ABSTRAK
Cagar biosfir Giam Siak Kecil (GSK) merupakan ekosistem paparan banjiran yang unik dengan sumberdaya ikan yang beragam. Terdapat beberapa permasalahan terkait pemanfaatan sumberdaya perikanan diantaranya penurunan jumlah dan jenis sumberdaya perikanan. Salah satu upaya pengelolaan perikanan yang digunakan adalah pendekatan ekosistem (Ecosystem Approach to Fisheries Management/EAFM). Tulisan ini bertujuan untuk merumuskan pengelolaan sumberdaya perikanan melalui pendekatan ekosistem di rawa banjiran GSK Provinsi Riau. Jenis ikan yang ditemukan sebanyak 37 jenis ikan, 10 jenis diantaranya merupakan ikan ekonomis penting, sementara 5 jenis ikan mengalami kelangkaan diantaranya arwana (Schleropages aureus), belida (Chitala $s p$ ), patin (Pangasius $s p$ ), jalai (Channa maruliodes). Nilai beberapa domain pada pengelolaan perikanan GSK menunjukkan skor pada kategori buruk (dibawah reference point) yakni pada domain penangkapan, kelembagaan dan ekonomi. Namun, secara umum kondisi pengelolaan rawa banjiran GSK tergolong dalam kategori sedang (nilai 1,53). Focus group discussion merumuskan langkahlangkah pengelolaan yang diperlukan diantaranya: 1) restocking ikan asli. 2) pengembangan kawasan suaka perikanan, 3) peningkatan pengawasan terhadap praktek-praktek penangkapan ikan ilegal dan merusak, 4) penguatan kelembagaan pengelolaan perikanan, dan 5) monitoring hasil tangkapan ikan beserta evaluasi pengelolaannya.
\end{abstract}

Kata Kunci: Pendekatan ekosistem; Giam Siak Kecil; Pengelolaan

\begin{abstract}
Giam Siak Kecil Biosphere Reserve is a part of unique floodplain ecosystem, which is inhabited by various fresh water fish species. The catches of some native species have curtailed over the last decade since the local fishers often use destructive fishing practices and gears. A sustainable management approach needs to be addressed to avoid over-exploitation and to restore the stock. This research aimed to formulate proper management approach that can be applied to the floodplain ecosystem of Giam Siak Kecil Biosphere Reserve. The research found that at least 37 species of fish were recorded, 10 of them were economically important species. There were five species categorized as rare species such as Arwana (Schleropages aureus), Belida (Chitala sp), Patin (Pangasius sp), and Jalai (Channa maruliodes). EAFM indikators showed that the lowest score (below the reference point) were found on fishery domain, organization domain, and economy domain. Nevertheless, it could be concluded that floodplain ecosystem of Giam Siak Kecil Biosphere Reserve was categorized in middle class category, with average scores of 1.53. Based on the findings above, the formulation of management purposed should be addressed to: 1) restocking native fishes, 2) developing fishery sanctuary, 3) increase surveillance of illegal fishing practices, 4) strengthening fishers organizations, 5) monitoring and evaluating the catch on weekly or monthly basis.
\end{abstract}

Keywords: Ecosystem approach; Giam Siak Kecil; Management 


\section{PENDAHULUAN}

Giam Siak Kecil (GSK) ditetapkan oleh United Nations Educational, Scientific and Cultural Organization (UNESCO) pada tahun 2009 sebagai cagar biosfir ke tujuh di Indonesia yang merupakan bagian dari suaka margasatwa Cagar Biosfir Giam Siak Kecil (GSK)-Bukit Batu (BB) di Provinsi Riau (Fujita et al., 2012; Rushayati et al., 2015). Cagar Biosfir GSK memiliki karakteristik yang spesifik antara lain terdapat kawasan rawa banjiran dalam zona intinya (core zone) dimana tanaman disekitarnya merupakan kawasan konservasi dan hutan produksi yang tidak dikonversi (Husnah et al., 2013).

Keberadaan Sungai Siak Kecil berikut rawa banjirannya merupakan bagian dari sistem perairan di Suaka Margasatwa GSK yang terletak di zona inti (Jarvie et al., 2003), namun sebelum ditetapkan sebagai cagar biosfir hingga saat ini, perairan tersebut telah dimanfaatkan masyarakat lokal untuk berbagai kegiatan termasuk kegiatan perikanan. Menurut UU No. 5 Tahun 1990 Tentang Konservasi Sumber Daya Hayati dan Ekosistemnya, pemanfaatan kawasan suaka alam termasuk didalamnya Cagar Biosfir Giam Siak Kecil tidak diperbolehkan kecuali hanya untuk kepentingan penelitian, ilmu pengetahuan, pendidikan, maupun kegiatan pembinaan habitat yang dimaksudkan untuk menjaga kelestarian satwa yang ada didalamnya.

Sejak Cagar Biosfir GSK-BB ditetapkan oleh UNESCO pada tahun 2009, terdapat beberapa permasalahan terkait pemanfaatan sumber daya khususnya sumber daya perikanan di rawa banjiran dalam zona inti. Pembatasan kegiatan perikanan oleh pihak terkait (Pemerintah) seperti Balai Konservasi Sumber Daya Alam (BKSDA) kepada masyarakat lokal berpotensi menimbulkan konflik antar pemerintah dan masyarakat lokal yang telah lama mendiami kawasan di dalam zona inti disekitar rawa banjiran GSK. Disisi lain, pemanfaatan sumber daya perikanan di dalam kawasan rawa banjiran GSK juga telah mengakibatkan ancaman kepunahan terhadap beberapa jenis ikan yang selama ini menjadi target utama seperti jenis belida (Chitala lopis) dan jenis ikan arwana merah (Scleropages aureus) yang sudah jarang ditemukan di Sungai Siak (Kasim et al., 2015). Pemahaman masyarakat terhadap pengelolaan berkelanjutan sumberdaya ikan di rawa banjiran masih sangat rendah sehingga cara eksploitasinya juga tanpa memperhatikan kelestariannya (Koeshendrajana \& Hoggarth, 1998).

Saat ini, pengelolaan perikanan dengan pendekatan ekosistem (Ecosystem Approach to Fisheries Management/EAFM) menjadi salah satu pendekatan yang digunakan dalam pengelolaan perikanan (Jaya \& Zulbainarni, 2015; Kusnandar \& Mulyani, 2015). Pendekatan EAFM bertujuan agar tercapai suatu pengelolaan perikanan yang terpadu, menyeluruh, dan berkelanjutan dengan tetap menyeimbangkan aspek sosial-ekonomi, pengetahuan, informasi dan ketidakpastian tentang komponen abiotik-biotik, serta interaksi manusia dalam ekosistem (Kementerian Kelautan dan Perikanan RI, WWF Indonesia dan Pusat Kajian Sumberdaya Pesisir dan laut-IPB, 2012). Penelitian sumberdaya perikanan di Giam Siak Kecil telah dilaksanakan pada tahun 2013 oleh Kasim et al., (2015) tentang "Kajian Pengelolaan Ekosistem Rawa Banjiran Gian Siak Kecil Melalui Pendekatan Ekosistem (EAFM)" dan Husnah et al., (2013) tentang "Identifikasi Komponen Penyusun Pengelolaan Perikanan Di Rawa Banjiran Giam Siak Kecil, Provinsi Riau". Tulisan ini bertujuan untuk merumuskan pengelolaan sumberdaya perikanan melalui pendekatan ekosistem di rawa banjiran Giam Siak Kecil Provinsi Riau.

\section{KARAKTERISTIK HABITAT GIAM SIAK KECIL}

Luas areal Cagar Biosfir GSK-BB sekitar 705.271 ha, yang termasuk wilayah Kabupaten Bengkalis $70 \%$, Kabupaten Siak sekitar $30 \%$. Berdasarkan zonasinya, area inti dengan luas sekitar 178.722 ha (25\%), zona penyangga sekitar $222.425 \mathrm{ha}(32 \%)$, dan area transisi sekitar 304.123 ha (43\%). Luas areal inti (178.722 ha) yang masuk Kabupaten Bengkalis seluas 121.963 ha (68\%) dan Kabupaten Siak 56.759 ha $(32 \%)$ (Sinaga, 2015; Badan Penelitian dan Pengembangan Provinsi Riau, 2013). Letak Cagar Biosfir Giam Siak Kecil-Bukit Batu dapat dilihat pada Gambar 1. 


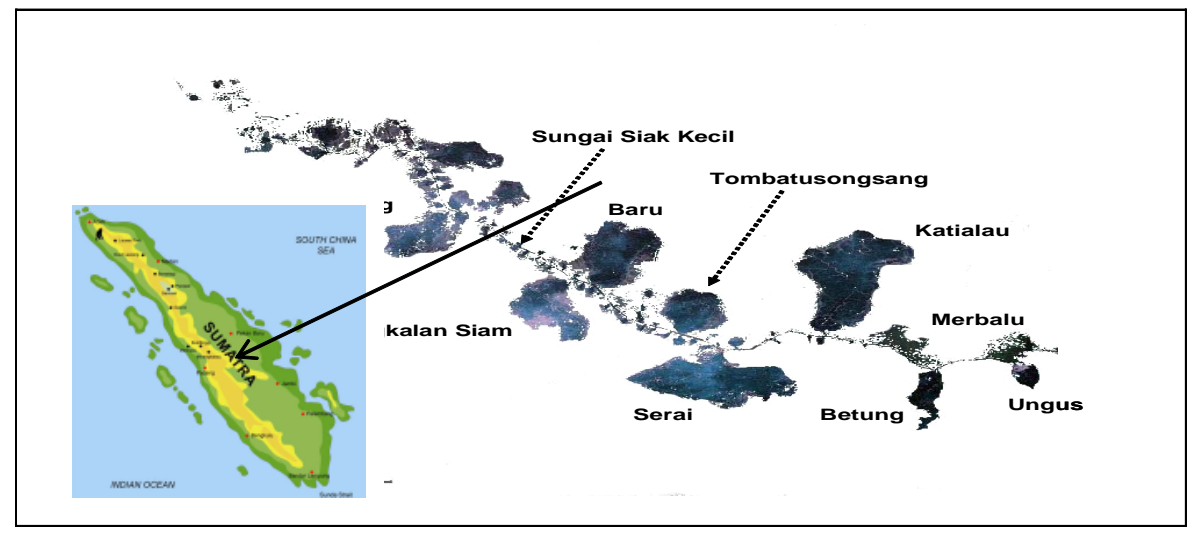

Gambar 1. Peta lokasi Giam Siak Kecil.

Figure 1. Map of Giam Siak Kecil.

Disepanjang Sungai Siak Kecil dari bagian hulu hingga hilir terdapat tipe ekosistem lahan rawa yang terdiri atas ekosistem sungai permanen (permanent river) dan ekosistem rawa. Terdapat sungai dan rawa lebak (grassland) yang terdiri atas swamp, marsh, bog dan danau rawa banjiran/tasik (floodplain lake) yang terendam air secara semi permanen (Husnah \& Prianto, 2011). Disepanjang sungai Siak, terdapat beberapa tasik diantaranya tasik Sigalanggang, Baru, Tangkalan Siam, Tombatusonsang, Katialau, Serai, Betung, Merbalu, Ungus, Besingin dan Air Hitam. Prianto (2015); Umar et al. (2015) menyatakan bahwa perairan rawa banjiran merupakan kawasan perikanan paling produktif khususnya perikanan tangkap namun kegiatan perikanan sangat bersifat musiman.

Lahan gambut merupakan kawasan marginal yang banyak mengalami alih fungsi menjadi perkebunan dan perumahan dan telah menjadi salah satu kawasan yang paling terancam saat ini ( $\mathrm{Ng} \&$ Kotellat, 1992 dalam Fahmi et al., 2015). Beberapa karakteristik ekstrim dari lahan gambut adalah: warna air coklat dan terlihat hitam jika terkena sinar, bersifat asam ( $\mathrm{pH}$ rendah), air cenderung stagnan atau tergenang dalam cekungan, bervegetasi, substratnya lumpur dan serasah, kandungan oksigen dan kalsium rendah, tanahnya miskin hara, populasi biota yang menghuni lahan gambut cenderung merupakan populasi kecil dan unik, hampir semua ikan hias lahan gambut memiliki corak warna yang menarik (Shah et al. 2006; Umar \& Prianto, 2016).

\section{STATUS SUMBERDAYA IKAN}

\section{a. Keanekaragaman Sumber Daya Ikan}

Perubahan komposisi jenis dan keragaman ikan di Giam Siak Kecil sedikit banyaknya akan dapat mempengaruhi hasil tangkapan nelayan. Hasil penelitian Husnah et al., (2013) bahwa jumlah jenis ikan di Giam Siak Kecil yang ditemukan sebanyak 37 jenis yang berasal dari 12 familia, dengan hasil tangkapan tertinggi pada bulan November di stasiun Air Hitam. Dari 12 familia tersebut kelimpahan relatif didominasi oleh familia Siluridae dari spesies Wallago leerii. Hasil survei tahun 2015 jenis-jenis ikan ditemukan di Giam Siak Kecil sebanyak 39 jenis.

Menurut Kottelat et al., (1996) semakin panjang dan lebar ukuran suatu perairan semakin banyak pula jumlah jenis ikan yang menempatinya. Adanya hubungan positif antara kekayaan jenis dengan suatu area yang ditempati tergantung pada dua faktor. Pertama, peningkatan jumlah mikro habitat akan dapat meningkatkan keragaman. Kedua, area yang lebih luas sering memiliki variasi habitat yang lebih besar dibanding dengan area yang lebih sempit (Wooton, 1991). Keasaman yang tinggi dan sumber karbon yang dominan berasal dari serasah di Giam Siak Kecil menyebabkan hanya ikan jenis rawa (black fish) dan jenis ikan dengan rantai makanan detritus feederdan predator yang mampu beradaptasi dengan kondisi tersebut (Marini et al., 2011).

\section{b. Ikan Dominan dan Spesies Penting}

Hasil analisa data hasil tangkapan ikan di perairan Giam Siak Kecil, terdapat 7 jenis ikan yang mendominasi perairan diantaranya baung (Hemibagrus nemurus), baung layar (Bagrichthys macracanthus), pimping (Parachila oxygastroides), selais (Kryptopterus lais), selincah (Belontia hasseltii), tapa (Wallago leeriii), dan toman (Channa melastoma). Ke-tujuh jenis ikan tersebut terdiri dari lima jenis ikan karnivora dan dua jenis ikan omnivora.

Jenis ikan ekonomis penting di GSK sebanyak 10 jenis yang keseluruhannya merupakan ikan karnivora. Jenis ikan tersebut diantaranya baung (Hemibagrus nemurus), selais balik tulang 
(Kryptopterus micronema), lais muncung (Kryptopterus apogon), lais sungut (Ompok eugeneiatus), lais tapa (Kryptopterus limpok), selais (Kryptopterus lais), tapa payu (Silurichthys phaiosoma), tapa (Wallago leeriii), gabus (Channa striata) dan toman (Channa melastoma).

\section{c. Ikan Langka dan Hampir Punah}

Beberapa jenis ikan telah mengalami penangkapan intensif sehingga menyebabkan terjadinya penurunan bahkan kelangkaan. Penggunaan alat tangkap dan cara penangkapan yang tidak ramah lingkungan seperti penggunaan tuguk dengan mata jarring $<2$ inci disinyalir menjadi salah satu penyebab menurunnya keragaman jenis dan kelangkaan ikan. Beberapa jenis ikan yang telah mengalami kelangkaan dan bahkan hampir punah adalah arwana (Schleropages aureus), belida (Chitala sp), patin (Pangasius sp), jalai (Channa maruliodes).

\section{STATUS PEMANFAATAN SUMBERDAYA IKAN}

\section{Aktivitas Penangkapan}

Aktivitas penangkapan merupakan kegiatan yang paling dominan dilakukan masyarakat di kawasan Giam Siak Kecil. Hasil tangkapan ikan pada rawa banjiran Giam Siak Kecil berkaitan erat dengan fluktuasi tinggi muka air. Tren Catch per Unit Effort (CPUE) hasil tangkapan ikan menurut musim mengalami fluktuasi mengikuti perubahan muka air. Biasanya puncak penangkapan ikan atau hasil tangkapan tertinggi di rawa banjiran terjadi pada musim kemarau, sebaliknya mengalami penurunan pada saat musim penghujan. Pola perubahan hasil tangkapan berdasarkan musim ini merupakan siklus yang terjadi setiap tahunnya (Utomo, 2016; Prianto et al., 2013; Hoggarth et al., 1999).
Pada alat tangkap lukah (pot trap) hasil tangkapan ikan dari beberapa nelayan menunjukkan pada saat air mulai turun yang terjadi antara bulan Februari hingga Mei, hasil tangkapan lukah cenderung menurun dengan kisaran tangkapan 2-5 kg/hari/nelayan. Pada saat air rendah (bulan Mei hingga Agustus) hasil tangkapan meningkat dengan kisaran tangkapan antara 3-6 kg/hari/nelayan. Pada saat air terendah (akhir bulan Juni) terjadi penurunan hasil tangkapan dengan kisaran 1-3 kg, dan hasil mulai meningkat kembali pada saat air besar dengan hasil tangkapan pada kisaran 5-25 kg/hari/nelayan. Hasil tangkapan ikan dengan jaring menunjukkan tingkah laku yang sedikit berbeda dengan alat tangkap lukah. Hasil tangkapan ikan dengan jaring cenderung meningkat pada saat air tergenang cukup lama (Mei-Agustus) dengan kisaran hasil tangkapan 4-8 kg/hari/nelayan dan saat tinggi muka air tertinggi yaitu pada bulan November dengan kisaran hasil tangkapan $5-16 \mathrm{~kg} /$ hari/nelayan (Husnah et al., 2013).

Perubahan hasil tangkapan ikan (CPUE) di Giam Siak Kecil tidak hanya dipengaruhi oleh musim tetapi juga akibat dari tekanan penangkapan dan perubahan fisik habitat. Akibat dari aktifitas tersebut perubahan CPUE ikan di GSK menjadi menurun. Hasil wawancara dengan para nelayan diperoleh perubahan CPUE hasil tangkapan nelayan selama 10 tahun terakhir mengalami perubahan yang sangat signifikan. Pada tahun 2005 sebanyak 36,4\% nelayan dapat menangkap ikan 30-100 kg/bulannya namun tahun 2015 hanya 27,3 \% saja nelayan yang mampu menangkap sebanyak tersebut. Selanjutnya pada tahun 2015 , sebanyak $40,9 \%$ nelayan hanya mampu menangkap ikan $<30 \mathrm{~kg} / \mathrm{bulan}$ sedangkan 10 tahun yang lalu (2005) hanya 4,5\% nelayan yang hanya mendapatkan hasil $<30 \mathrm{~kg} / \mathrm{bulan}$ (Kasim et al., 2015).

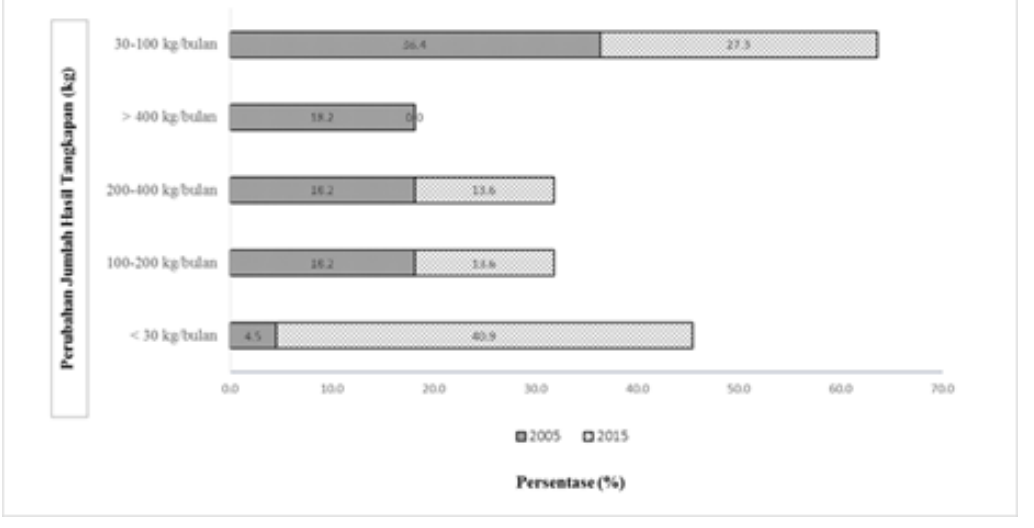

Gambar 2. Perubahan Hasil Tangkapan ikan Tahun 2005 dan 2010.

Figure 2. The change of fish catches in 2005 and 2010. 


\section{Aktivitas Budidaya}

Aktivitas budidaya ikan di Giam Siak Kecil saat ini belum berkembang dengan baik. Walaupun upaya untuk pengembangan budidaya ikan lokal dengan menggunakan jaring apung pernah diinisiasi oleh Pemerintah Daerah Kabupaten Bengkalis, namun upaya tersebut belum membuahkan hasil. Permasalahan yang dihadapi oleh masyarakat adalah ketersediaan benih ikan lokal dan teknologi budidaya ikan belum dikuasai dengan baik. Selain itu, masyarakat belum terbiasa dengan kegiatan budidaya yang memerlukan biaya besar dan waktu pemeliharaan lama.

\section{STATUS PENGELOLAAN SUMBERDAYA PERIKANAN}

Pengelolaan kawasan Cagar biosfir ini masih dibawah Balai Konservasi Sumber Daya Alam (BKSDA) Kementerian Lingkungan Hidup dan Kehutanan (KLHK) (Rushayati et al., 2015). Konsep pengelolaan GSK menurut kehutanan adalah "no take zone" yang artinya dilarang melakukan pengambilan terhadap sesuatu apapun di dalam kawasan tersebut. Konsep tersebut berbeda dalam konteks pengelolaan perikanan, dimana masyarakat masih boleh memanfaatkan sumberdaya perikanan namun harus memperhatikan antara keseimbangan ekologi, ekonomi dan sosial-budaya.

Faktanya yang diperleh lapangan bahwa didalam atau diperbatasan kawasan cagar biosfir tersebut banyak dihuni oleh masyarakat yang hidup selama puluhan bahkan ratusan tahun.Walaupun menurut Kementerian LHK secara "de jure" tidak boleh ada aktifitas didalamnya, namun faktanya masyarakat tetap tinggal dan melakukan pemanfaatan terhadap hasil hutan dan perikanan. Kondisi ini yang menyebabkan diperlukan upaya pengelolaan secara lestari melalui pendekatan EAFM.

\section{PERMASALAHAN PENGELOLAAN SUMBER DAYA IKAN}

Berdasarkan analisis hasil wawancara dengan kelompok nelayan, beberapa isu dan permasalahan penting dalam kegiatan perikanan di rawa banjiran GSK berdasarkan skala prioritas adalah: i) terjadinya penurunan jumlah hasil tangkapan nelayan, ii) penurunan jumlah jenis-jenis ikan yang mereka temukan yang berakibat pada penurunan pendapatn nelayan, iii) penurunan ketebalan hutan, serta iv) isu pencemaran lingkungan (Gambar 3).

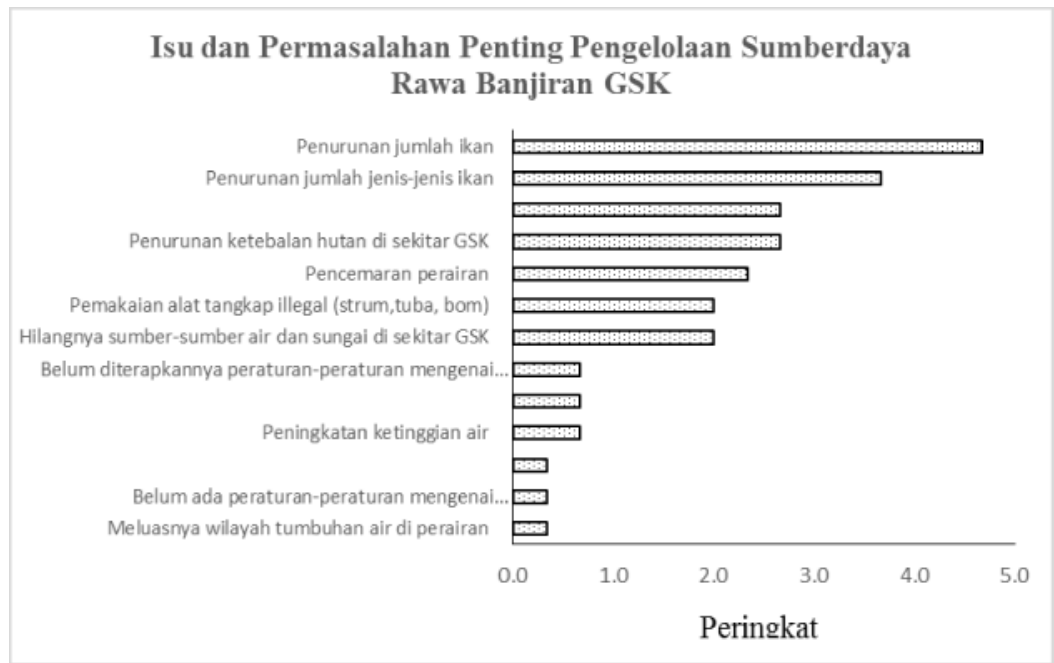

Gambar 3. Persepsi masyarakat terhadap isu dan permasalahan penting pengelolaan sumberdaya rawa banjiran GSK tahun 2015.

Figure 3. Local people perception on the main issues and problems in resource management of Giam Siak Kecil.

Isu dan permasalahan utama seperti penurunan hasil tangkapan (jumlah ikan) dan penurunan jumlah jenis ikan ditunjukkan oleh semakin sulitnya nelayan menangkap beberapa jenis ikan ekonomis penting seperti belida (Chitala lopis), ikan arwana merah (Sclerophages aureus) (Direktorat KKJI, 2012), dan jenis ikan tengkusung.

\section{PENENTUAN DOMAIN INDIKATOR}

Implementasi EAFM memerlukan perangkat indikator yang dapat digunakan sebagai alat monitoring dan evaluasi mengenai sejauh mana pengelolaan perikanan sudah menerapkan prinsip-prinsip pengelolaan berbasis ekosistem (Budiarto et al. 2015). 
Analisis data dilakukan dengan menggunakan pendekatan multi-criteria analysis (MCA) dimana satu set kriteria dibangun sebagai basis bagi analisis keragaan wilayah pengelolaan perikanan yang dilihat dari pendekatan ekosistem dalam pengelolaan

Tabel 1. Batasan/Kriteria Nilai Skor Atribut EAFM Table 1. Limits/Criteria Score Attributes of EAFM perikanan (EAFM) melalui pengembangan indeks komposit (Adrianto et al., 2005). Pemberian skor dilakukan berdasarkan hasil yang diperoleh dari setiap atribut dengan membandingkan dengan reference point (Tabel 1).

\begin{tabular}{|c|c|c|c|}
\hline \multicolumn{2}{|c|}{$\begin{array}{c}\text { Batasan Skor Indikator/ } \\
\text { Limits/Criteria Score }\end{array}$} & \multirow{2}{*}{$\begin{array}{l}\text { Deskripsi/ } \\
\text { Description }\end{array}$} & \multirow{2}{*}{$\begin{array}{l}\text { Warna/ } \\
\text { Colour }\end{array}$} \\
\hline $\begin{array}{l}\text { Batasan Baru/ } \\
\text { Lower Limits }\end{array}$ & $\begin{array}{c}\text { Batasan Atas/ } \\
\text { Upper Limits }\end{array}$ & & \\
\hline 1 & 1.5 & Rendah/Buruk & \\
\hline 1.51 & 2.50 & Sedang & \\
\hline 2.51 & 3.00 & Tinggi/Baik & \\
\hline
\end{tabular}

Terdapat enam domain indikator EAFM yang digunakan dalam pengelolaan sumberdaya perikanan di GSK yaitu: (1) domain sumberdaya ikan; (2) domain habitat dan ekosistem; (3) domain penangkapan ikan; (4) domain lembaga; (5) domain sosial; dan (6) domain ekonomi (Lampiran 1).

\section{Domain Sumberdaya Ikan}

Domain sumberdaya ikan terdiri dari 4 indikator: 1) tren hasil tangkapan, 2) perubahan ukuran, 3) proporsi ikan juwana yang ditangkap, 4) komposisi spesies hasil tangkapan. Dilihat dari domain sumberdaya ikan, di GSK telah terjadi tren penurunan hasil tangkapan dan perubahan ukuran ikan selama beberapa tahun terakhir. Secara umum domain sumberdaya ikan mendapatkan nilai sedang (warna kuning). Ini menunjukkan indikasi kerusakan sumberdaya meskipun masih dalam kategori sedang.

\section{Domain Habitat dan Ekosistem}

Domain habitat dan ekosistem terdiri dari empat indikator yaitu :1) indeks pencemaran, 2) habitat unik/ khusus, 3) modifikasi lingkungan dan 4) tumbuhan sempadan. Berdasarkan penilaian ke-empat indikator,modifikasi lingkungan memperoleh skor yang paling rendah (merah). Ini menunjukkan kondisi Giam Siak Kecil telah mengalami modifikasi lingkungan. Modifikasi lingkungan yang terjadi akibat aktifitas manusia di sekitar kawasan GSK seperti perkebunan dan pembalakan liar yang menyebabkan rusaknya hutan dan vegetasi sepadan sungai. Namun jika dilihat secara keseluruhan pada domain habitat dan ekosistem setelah dilakukan penilaian terhadap seluruh indikator maka domain ini mendapatkan nilai sedang (warna kuning). Hal ini menunjukkan tingkat kerusakan pada domain ini berada pada tingkat sedang.

\section{Domain Penangkapan}

Domain penangkapan yang digunakan ada tiga indikator: 1) perubahan upaya penangkapan, 2) praktek penangkapan yang tidak ramah lingkungan, dan 3) perubahan fishing ground. Pada domain ini, seluruh nilai ketiga indikator ini mendapatkan skor yang rendah (merah). Ini menunjukkan di GSK telah terjadi perubahan penangkapan, praktek penangkapan yang tidak ramah lingkungan dan perubahan daerah penangkapan.

\section{Domain Lembaga}

Domain lembaga yang dikembangkan dalam pendekatan EAFM di GSK terdiri dari 6 indikator yaitu: 1) kepatuhan terhadap prinsip-prinsip perikanan yang bertanggung jawab dalam pengelolaan perikanan yang telah ditetapkan baik secara formal maupun nonformal, 2) kelengkapan aturan main dalam pengelolaan perikanan, 3) mekanisme pengambilan keputusan, 4) rencana pengelolaan perikanan, 5) tingkat sinergisitas kebijakan dan kelembagaan pengelolaan perikanan, dan 6) kapasitas pemangku kepentingan. Pada domain lembaga, secara keseluruhan mendapat nilai rendah (merah). Ini menunjukkan domain lembaga dengan indikatorindikator yang ada belum dikembangkan dan dipatuhi oleh masyarakat.

\section{Domain Sosial}

Domain sosial terdiri dari tiga indikator diantaranya: 1) partisipasi pemangku kepentingan, 2) konflik perikanan, 3) pemanfaatan pengetahuan lokal dalam pengelolaan sumberdaya ikan (termasuk didalamnya TEK-traditional ecological knowledge). Dari ketiga indikator yang ada, nilai dari partisipasi pemangku kepentingan masih rendah (merah). Hal ini dapat 
dirasakan oleh masyarakat nelayan bahwa partisipasi peran tokoh adat, agama, tokoh masyarakat, pemerintah daerah masih belum memberikan kontribusi yang nyata terhadap pengelolaan perikanan. Namun dilihat secara umum, domain sosial mendapat nilai sedang (warna kuning).

\section{Domain Ekonomi}

Untuk domain ekonomi terdiri dari 3 indikator: 1) kepemilikan aset alat tangkap, 2) pendapatan rumah tangga perikanan (RTP) dan 3) rasio pendapatan perikanan terhadap rasio pendapatan rumah tangga. Dari ketiga indikator yang ada hanya pendapatan rumah tangga perikanan yang mendapat nilai sedang (kuning) sedangkan kepemilikan aset alat tangkap dan rasio pendapatan perikanan mendapat nilai rendah (merah). Dilihat secara umum, domain sosial mendapatkan nilai yang rendah (warna merah).

Selanjutnya dilihat dari seluruh nilai domain yang diaggregat maka kondisi pengelolaan rawa banjiran Giam Siak Kecil tergolong dalam kategori sedang atau warna kuning (nilai 1,53). Ini menunjukkan bahwa kondisi pengelolaan ekosistem rawa banjiran Giam Siak Kecil dalam kondisi yang kurang baik.

\section{STRATEGI PENGELOLAAN DENGAN PENDEKATAN EKOSISTEM}

Pengelolaan perikanan dapat dicapai dengan strategi yang tepat dengan melibatkan seluruh pemangku kepentingan. Hasil diskusi kelompok terarah (FGD) yang melibatkan masyarakat nelayan, pemerintah daerah, akademisi maupun lembaga swadaya masyarakat telah menghasilkan beberapa peluang perbaikan sistem pengelolaan perikanan yang disusun ke dalam skala prioritas diantaranya: i) perlunya pelepas liaran kembali ikan asli (native species) di rawa banjiran GSK, ii) pentingnya zonasi wilayah konservasi dan pemanfaatan SDI, iii) kegiatan domestikasi ikan asli di Balai Benih Ikan setempat yang dikoordinasi oleh Dinas Perikanan Daerah, iv) rehabilitasi hutan dan v) pembatasan jumlah alat tangkap dan ukuran mata jaring (Gambar 4).

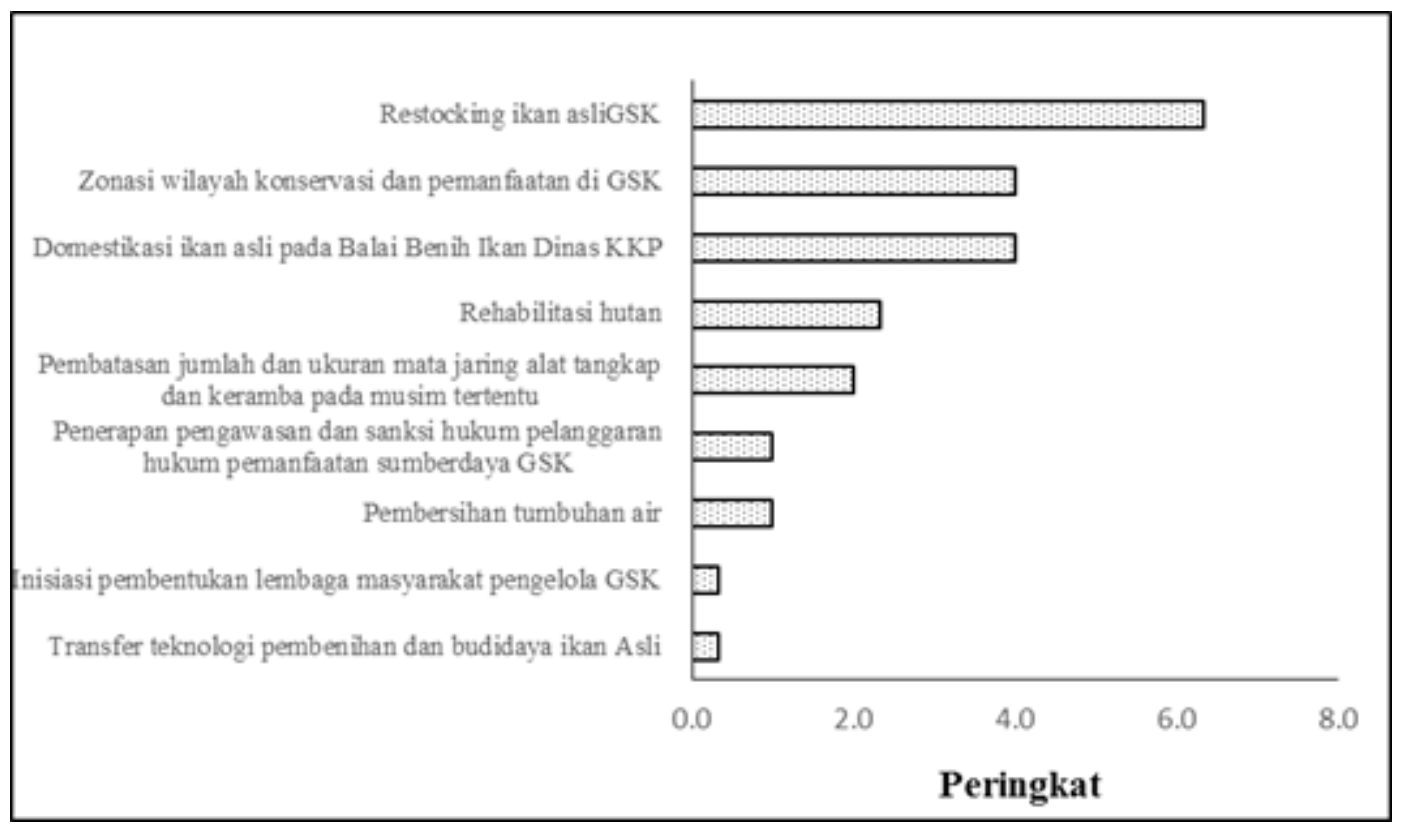

Gambar 4. Peluang perbaikan sistem pengelolaan perikanan yang diusulkan dalam Focus Group Discussion. Figure 4. Opportunities of fisheries management system improvements were proposed in Focus Group Discussion.

Dilihat dari strategi yang diusulkan pada Gambar 4 diharapkan upaya tersebut dapat menyelesaikan permasalahan yang dihadapi. Penyebab dari nilai domain yang berwarna merah disebabkan karena sebagian besar aktivitas penangkapan, regulasi yang kurang mendukung dan cara penangkapan yang merusak sumberdaya ikan dan ekosistemnya. Untuk mengubah domain pengelolaan dari buruk (warna merah) perlu upaya penyelamatan GSK menjadi lebih baik. Upaya penyelamatan sumberdaya ikan yang dimaksud harus bersifat implementatif dan fokus pada permasalahan sesuai masukan dari masyarakat dan stakeholder lainnya. Peluang perbaikan melalui sistem: i) pelepas liaran kembali ikan asli (native species), ii) pentingnya zonasi wilayah konservasi dan pemanfaatan SDI dan iii) kegiatan domestikasi ikan 
asli di Balai Benih Ikan setempat dapat menyelesaikan permasalahan yang dihadapi GSK.

\section{KESIMPULAN DAN REKOMENDASI}

\section{Kesimpulan}

Ekosistem rawa banjiran dalam Cagar Biosfir GSK berperan penting sebagai habitat utama beberapa jenis ikan langka dan ikan asli di perairan umum daratan. Namun demikian, indikasi terjadinya hasil tangkapan nelayan yang menurun, praktek penangkapan tidak ramah lingkungan dan sumberdaya, serta perubahan ukuran ikan tangkapan pada beberapa wilayah paparan banjiran GSK menunjukkan perlunya penetapan upaya dan langkah-langkah pengelolaan yang berkelanjutan.

Dari hasil analisis EAFM diperoleh beberapa indikator dengan kategori kurang baik yang diindikasikan dengan nilai merah (score di bawah reference point pada hampir sebagian besar domain). Meskipun demikian, secara umum kondisi pengelolaan rawa banjiran Giam Siak Kecil tergolong dalam kategori sedang (nilai 1,53).

Beberapa strategi pengelolaan yang diusulkan diantaranya:i) pelepas liaran kembali ikan asli (restocking native species), ii) membuat zonasi wilayah konservasi dan pemanfaatan SDI dan iii) melakukan domestikasi ikan asli di Balai Benih Ikan setempat dapat menyelesaikan permasalahan yang dihadapi GSK.

\section{Rekomendasi}

Dalam model pengelolaan Giam Siak Kecil berdasarkan pendekatan EAFM, perlu dilakukan langkah-langkah pengelolaan efektif dan segera guna mencapai tujuan pengelolaan ekosistem rawa banjiran Giam Siak Kecil yang lebih sehat. Langkah-langkah tersebut meliputi hal-hal sebagai berikut: (1) Restocking ikan asli, (2) Pengembangan kawasan suaka perikanan pada beberapa tasik seperti Tasik Katialau dan Tasik Tombatosongsang, (3) peningkatan pengawasan terhadap praktek-praktek penangkapan ikan ilegal dan merusak melalui peran aktif Kelompok Pengawas Masyarakat, (4) penguatan kelembagaan pengelolaan perikanan, (5) monitoring hasil tangkapan ikan serta evaluasi pengelolaannya.

\section{PERSANTUNAN}

Penelitian ini merupakan bagian dari penelitian Kajian Pengelolaan Ekoistem Rawa Banjiran Giam Siak Kecil melalui Pendekatan Ekosistem (EAFM) Tahun Anggaran 2015.

\section{DAFTAR PUSTAKA}

Adrianto, L., Matsuda, Y., \& Sakuma, Y. (2005). Assessing local sustainability of fisheries system: A Participatory Qualitative System Approach to the Case of Yoron Island, Kagoshima Prefecture, Japan. Marine Policy. Elsevier Sciences. 29, 9-23

Badan Penelitian dan Pengembangan Provinsi Riau. (2013). Dukungan eksisting pengembangan riset Cagar Biosfir Giam Siak Kecil Bukit Batu, Riau. Badan Penelitian dan Pengembangan Provinsi Riau, p. 6-91.

Budiarto, A., Adrianto, L., \& Kamal, M. M. (2015). Status pengelolaan perikanan rajungan (Potunus Pelagicus) dengan pendekatan ekosistem di Laut Jawa (WPPNRI 712). J.Kebijak.Perik.Ind. 7(1), 924.

(Direktorat KKJI) Direktorat Kawasan Konservasi Jenis Ikan, (2012). Ikan air tawar langka Indonesia. Direktorat Kawasan Konservasi Jenis Ikan, p. 75.

Fahmi, M. R., Ginanjar, R., \& Kusumah, R. V. (2015). Keragaman ikan hias di lahan gambut Cagar Biosfir Bukit-Batu, Propinsi Riau. Prosiding Seminar Nasional Masyarakat Biodiversity Indonesia, 1(1), 51-58.

Fujita, M. S., Irham, M., Fitriana, Y.S., Samejima., Hiromitsu., Wijamukti, S., Haryadi, D. S., \& Muhammad, A. (2012). Mammals and Birds in Bukit Batu Area of Giam Siak Kecil-Bukit Batu Biosphere Reserve, Riau, Indonesia. Kyoto Working Papers on Area Studies, G-COE Series 126, 1-70.

Hoggarth, D. D., Cowan, V.J., Halls, A.S., McGregor, J.A., Garaway, C.A., Payne, A.I., \& Walcomme, R.L. (1999). Management guidelines for asian floodplain river fisheries. FAO Fisheries Technical Paper 384/2. Roma : FAO.

Jarvie, J., Jeyaraj, K., \& Hardiono, M. (2003). A high conservation value forest analysis of the Giam Siak Kecil Landscape - Riau, Sumatra. A report to WWF - International. p.73.

Jaya, I, \& Zulbainarni, N. (2015). Pengembangan dan ujicoba model evaluasi pengelolaan perikanan melalui pendekatan ekosistem. J.Kebijak.Perik.Ind, 7(2),115-131. 
Kasim, K., Husnah, Prianto, E., Triharyuni, S., \& Umar, C. (2015). Kajian pengelolaan ekosistem rawa banjiran Giam Siak Kecil melalui pendekatan ekosistem (EAFM). Laporan Teknis. Pusat Penelitian dan Pengembangan Perikanan. Jakarta. p.83.

Kementerian Kelautan dan Perikanan RI, WWF Indonesia dan Pusat Kajian Sumberdaya Pesisir dan laut-IPB.(2012). Modul Training: Penilaian Indikator Pendekatan Ekosistem Untuk Pengelolaan Perikanan (EAFM). Kementerian Kelautan dan Perikanan RI, WWF Indonesia dan Pusat Kajian Sumberdaya Pesisir dan laut-IPB WWF. p.32.

Kottelat, M., Whitten, A.J., Kartikasari, S.N., \& Wirjoatmodjo, S. (1996). Fishes of west Indonesia and Sulawesi. Periplus Edition Limited. Jakarta.

Koeshendrajana, S \& Hoggarth, DD. (1998). Harvest reserves in Indonesian river fisheries. Paper presented at Fifth Asian Fisheries Forum International 159. Conference of Fisheries and Food Security Beyond the Year 2000. 11 - 14 November. Chiang May.

Kusnandar \& Mulyani, S. (2015). Strategi pengelolaan sumberdaya perikanan berbasis ekosistem. OSEATEK, 9(1), 9-20.

Husnah \& Prianto, E. (2011). Karakteristik lingkungan perairan rawa: Studi kasus rawa banjiran suaka margasatwa Giam Siak Kecil. Dalam: Perikanan dan kondisi lingkungan sumberdaya ikan perairan umum daratan Riau.N.N. Wiadyana, A. K. Gaffar dan Husnah (eds). Bee Publishing. Palembang. p. 37-60.

Husnah., Ditya, Y.C., Marini, M., Koeshendrajana, S., Samiaji, J., Arisna, D., \& Juniarto, R.S. (2013). Identifikasi komponen penyusun pengelolaan perikanan di rawa banjiran Giam Siak Kecil, Provinsi Riau. Laporan Akhir. Balai Penelitian Perikanan Perairan Umum. p. 66.

Marini, M., Asyari, \& Herlan. (2011). Keragaman jenis ikan. Dalam: Perikanan dan kondisi lingkungan sumberdaya ikan perairan umum daratan Riau.Wiadyana, N. N; Gaffar, A. K \& Husnah (eds). Bee Publishing. Palembang. p. 141-230.
Prianto, E. (2015). Aspek reproduksi dan dinamika larva ikan sebagai dasar pengelolaan sumberdaya ikan di Paparan Banjiran Lubuk Lampam Provinsi Sumatera Selatan. Sekolah Pasca Sarjana Institut Pertanian Bogor. Disertasi. 125 hal.

Prianto, E., Kamal, M. M., Muchsin, I., \& Kartamihardja, E. S. (2013). Strategi pengelolaan perikanan paparan banjir Lubuk Lampam Kabupaten Ogan Komering llir, Sumatera Selatan Management Strategy of Floodplain Fisheries of Lubuk Lampam Ogan Komering Ilir, South Sumatera. J.Kebijak.Perik.Ind. 5(2), 58 57-66.

Rushayati, S. B., Meilani, R \& Hermawan, R. (2015). The threats of deforestation, Forest Fire, and $\mathrm{CO} 2$ Emission toward Giam Siak Kecil Bukit Batu Biosphere Reserve in Riau, Indonesia International Journal of Environmental, Chemical, Ecological, Geological and Geophysical Engineering, 9(8), 997-1004.

Shah, A.S.R.M., Chan, K. Y., Hashim, Z., \& Mansor, M. (2006). A recent survey of freshwater fishes of the Paya Beriah Peat Swamp Forest, North Perak, Malaysia. Journal Biosains, 17(1), 5164.

Sinaga, N. A. (2015). Kerjasama Jepang-Indonesia melalui Japan International Corporation Agency (JICA) di Cagar Biosfir Giam Siak Kecil-Bukit Batu, Kabupaten Bengkalis (2012-2014). Jom FISIP, 2(1), 1-14.

Umar, C, \& Prianto, E. (2016). Potensi ikan hias di lahan gambut sungai serkap dan peluang pemasarannya. Prosiding Simposium Nasional Ikan Hias. Balai Penelitian dan Pengembangan Budidaya Ikan Hias. p. 8-14.

Umar, C., Prianto, E., \& Sulaiman, P. S. (2015). Pengelolaan sumberdaya perikanan di Sungai Serkap Kabupaten Pelalawan Provinsi Riau. J.Kebijak.Perik.Ind. 7(2), 71-77.

Utomo, A. D. (2016). Strategi pegelolaan suaka perikanan rawa banjiran di Sumatera dan Kalimantan. J.Kebijak.Perik.Ind. 8(1), 14-20

Wooton, J. (1991). Ecology of Teleost Fishes. New York: Chapman \& Hall. 
Lampiran 1. Kriteria dan bobot masing-masing indikator Appendix 1. Criteria and weight ofindicator respectively

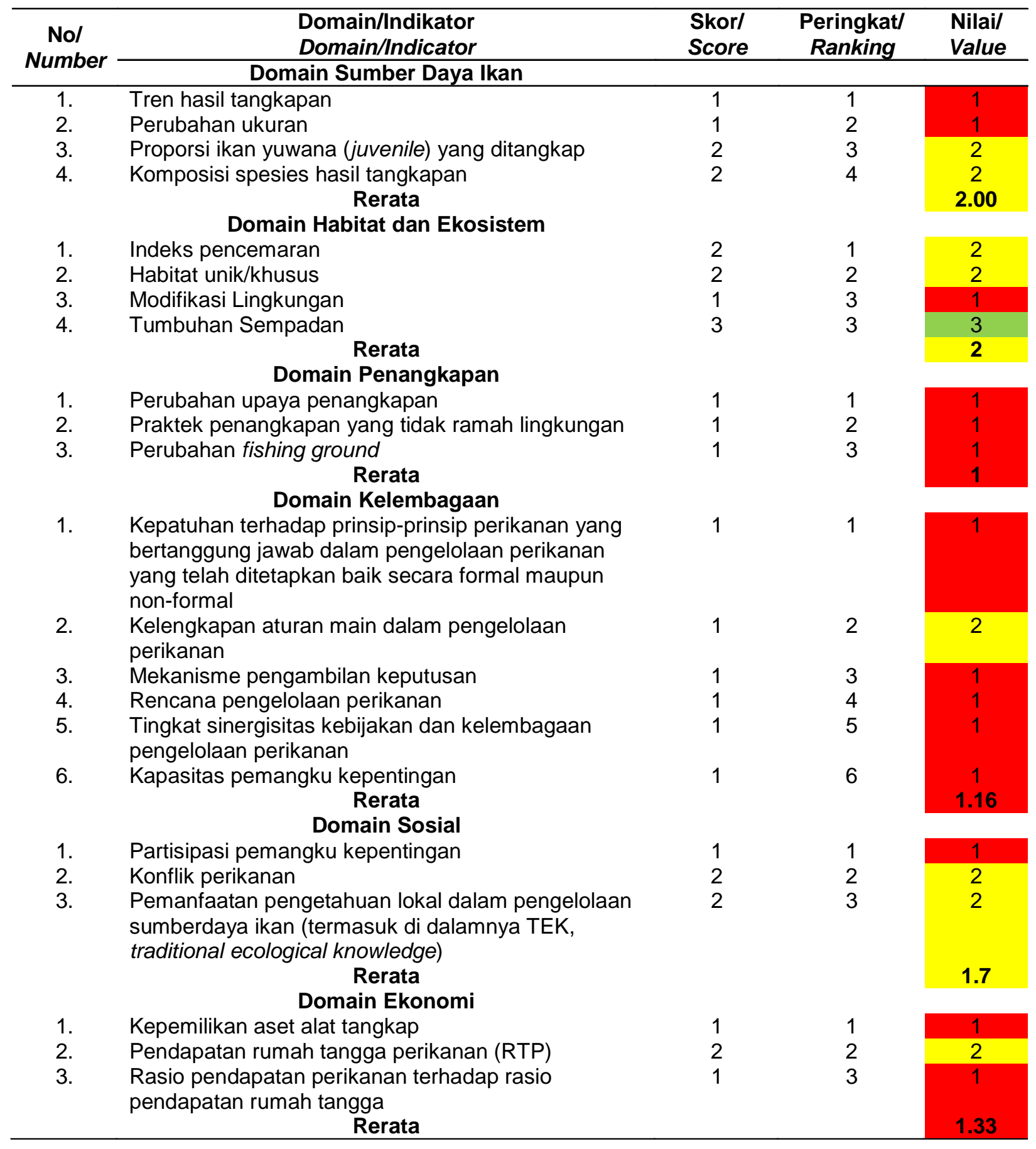

